Kemudi: Jurnal Ilmu Pemerintahan $\mid 259$

Volume 05 Nomor 02 Februari 2021

2622-9633 (Online)

Open Access at: https://ojs.umrah.ac.id/index.php/kemudi

DOI: https://doi.org/10.31629/kemudi.v5i02.2806

\title{
Regulasi Netralitas Aparatur Sipil Negara Pada Pemilihan Kepala Daerah Tahun 2020
}

\author{
Dewi Mustika Sari \\ Magister Ilmu Pemerintahan, Fakultas Ilmu Sosial dan Ilmu Politik \\ Universitas Lampung \\ dewimustikasari1885@gmail.com
}

\begin{abstract}
ABSTRAK
Pemungutan suara Pilkada 2020 akan diselenggarakan satu minggu lagi, sayangnya pelanggaran netralitas Aparatur Sipil Negara (ASN) masih menjadi momok dalam pelanggaran pemilihan. Berdasarkan data yang dihimpun Bawaslu hingga 16 November 2020 terdapat 1.038 pelanggaran netralitas ASN yang terdiri dari 934 merupakan temuan Bawaslu sedangkan 104 laporan masyarakat. Dari data tersebut KASN telah mengeluarkan rekomendasi 938 kasus, 5 kasus telah diproses, dan 95 kasus dinyatakan bukan pelanggaran. Pengawasan Netralitas pegawai ASN menjadi salah satu hal yang harus dikuatkan dalam mengatasi permasalahan netralitas ASN agar reformasi birokrasi di pemerintahan berjalan dengan cepat.
\end{abstract}

\section{Kata Kunci: Aparatur Sipil Negara, Netralitas, dan Pemilihan Kepala} Daerah

\section{Pendahuluan}

Komisi Aparatur Sipil Negara (KASN) adalah lembaga non struktural yang mandiri yang dibentuk berdasarkan Pasal 27 UU No. 5 tahun 2014 tentang Aparatur Sipil Negara, Sesuai Pasal 30 UU tersebut, KASN berfungsi sebagai pengawas pelaksanaan nilai dasar, kode etik dan kode perilaku ASN, serta penerapan sistem merit dalam kebijakan dan manajemen ASN pada instansi Pemerintah. Adapun tugas KASN, menurut Pasal 31 UU ASN, adalah menjaga netralitas pegawai ASN, melakukan pengawasan atas pembinaan profesi ASN dan melaporkan pelaksanaan tugas kepada Presiden.

Pegawai ASN berada dalam posisi yang dilematis dan terombang ambing oleh kepentingan politik. Di satu sisi, mereka adalah pegawai yang diangkat, ditempatkan, dipindahkan dan diberhentikan oleh Pejabat Pembina Kepegawaian (PPK) yang berstatus pejabat politik. Kondisi seperti ini membuat karier mereka sering dikaitkan dengan kepentingan politik PPK. Di sisi lain, ASN juga harus tetap bersikap netral untuk menjaga profesionalitasnya dalam menjalankan tata kelola pemerintahan dan pelayanan publiknya. ASN adalah pelaksana kebijakan dan pemegang kekuasaan dan kewenangan dalam 
pengelolaan anggaran dan sumber daya di dalam birokrasi. Hal ini mengakibatkan pegawai ASN dapat dijadikan sebagai alat bagi pejabat politik untuk dapat tetap mempertahankan/mendapatkan kewenangan dan kekuasaannya (Saputra, 2020).

Netralitas ASN saat ini menjadi isu yang banyak mendapat sorotan. Hal ini disebabkan oleh banyaknya pelanggaran pegawai ASN terhadap asas netralitas. Pelanggaran ini terjadi, terutama menjelang, pada saat, dan setelah pelaksanaan Pilkada yang berlangsung pada tahun 2015, 2017 dan 2018. Isu Netralitas ASN menjadi hal yang akan terus berlanjut ke depan dan strategis, karena adanya penyelenggaraan pemilu anggota legistlatif dan presiden/wakil presiden tahun 2019, serta pilkada serentak gelombang keempat tahun 2020 dan gelombang kelima tahun 2024. Sementara itu, pegawai ASN dituntut untuk bersikap netral dapat menjalankan tugasnya secara profesional oleh sebab itu penegakan netralitas ASN menjadi begitu penting (Saputra, 2020).

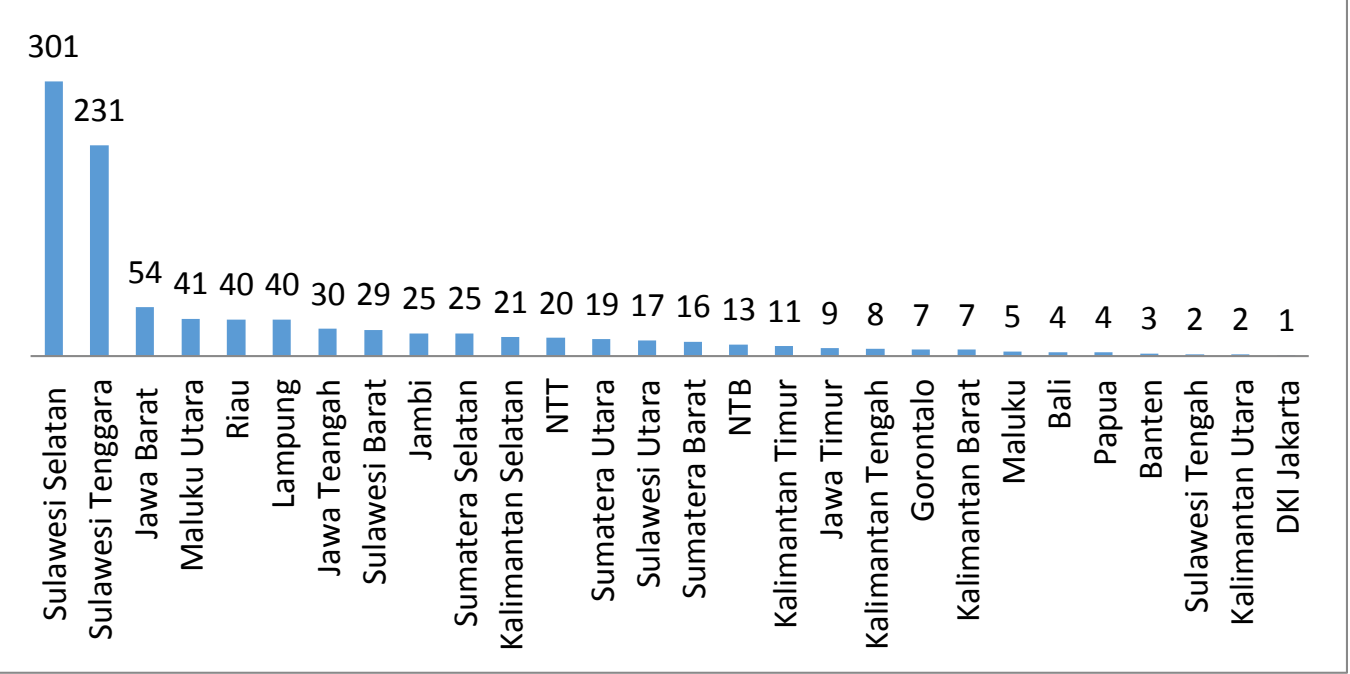

Gambar 1. Jumlah ASN Pelanggaran Netralitas ASN Per Provinsi Tahun 2019 Sumber: Komisi Aparatur Sipil Negara, (Data Per Desember 2019)

Gambar 1 menunjukkan bahwa data ASN pelanggaran netralitas tertinggi terjadi di Sulawesi Selatan (301 ASN), sedangkan DKI Jakarta mendai provinsi dengan jumlah pelanggaran ASN terendah (1 ASN). Terkait dengan tingginya kasus pelanggaran netralitas oleh pegawai ASN, ada kebutuhan mendesak untuk meninjau kembali sistem pengawasan yang berlaku. Netralitas merupakan salah satu asas yang penting dalam penyelenggaraan tugas pelayanan publik, tugas pemerintahan dan tugas pembangunan. Setiap 
pegawai ASN harus bersikap netral untuk dapat menjalankan tugasnya secara professional. Untuk menegakkan netralitas ASN, pemerintah telah mengeluarkan sejumlah peraturan perundang-undangan. Namun demikian, tingkat pelanggaran terhadap azas netralitas di kalangan pegawai ASN masih tinggi, terutama menjelang pelaksanaan Pilkada serentak. Sementara itu, ketidaknetralan pegawai ASN dapat menyebabkan terjadinya keberpihakan atau ketidakadilan dalam pembuatan kebijakan dan penyelenggaraan pelayanan yang pada akhirnya akan menimbulkan kerugian bagi masyarakat secara luas.

Salah satu aspek yang sangat penting dalam penegakan netralitas ASN ini adalah aspek Pengawasan. Sistem pengawasan ASN yang efektif sangat dibutuhkan untuk memastikan pegawai ASN dalam melaksanakan tugasnya mematuhi peraturan-perundang-undangan yang terkait netralitas ASN, guna menciptakan birokrasi yang profesional dan akuntabel. Adapun tugas KASN, menurut Pasal 31 UU ASN, adalah menjaga netralitas pegawai ASN, melakukan pengawasan atas pembinaan profesi ASN dan melaporkan pelaksanaan tugas kepada Presiden.

Dalam menjalankan tugasnya menjaga netralitas ASN, KASN menerima laporan terhadap pelanggaran netralitas ASN, melakukan penelusuran data dan informasi atas prakarsa sendiri terhadap dugaan pelanggaran netralitas ASN, dan melakukan upaya pencegahan pelanggaran terhadap netralitas ASN. Berdasarkan kewenangan tersebut. KASN sejak tahun 2015 sudah membangun sistem pengawasan, khususnya pengawasan yang bersifat represif. Sistem pengawasan yang bersifat represif adalah dengan menerima dan menindaklanjuti pengaduan dari masyarakat, lembaga pemerintah, ASN, LSM dan berbagai pihak untuk kasus pelanggaran terhadap netralitas ASN. Pengaduan ini, selanjutnya dapat dilakukan penyelidikan (investigasi) untuk mendapatkan bukti yang lebih lengkap untuk memberikan rekomendasi. Sampai dengan Desember 2018 jumlah aduan yang masuk ke KASN mencapai 491 aduan. Data menunjukkan kasus pelanggaran cenderung meningkat. KASN juga telah melakukan kerjasama dengan Bawaslu. Kerjasama dengan Bawaslu dan KASN dilakukan baik dalam melakukan sosialisasi, maupun menyampaikan data hasil temuan yang telah dilakukan oleh Bawaslu yang kemudian ditindaklanjuti oleh KASN yang terkait pelanggaran netralitas pegawai ASN. 


\section{Tinjauan Pustaka}

\section{Teori Partisipasi Pemilih}

Partisipasi politik merupakan suatu masalah yang penting dan banyak dipelajari terutama dalam hubungannya dengan negara- negara berkembang. Pada awalnya studi mengenai partisipasi politik hanya memfokuskan diri pada partai politik sebagai pelaku utama, akan tetapi dengan berkembangnya demokrasi, banyak muncul kelompok masyarakat yang juga ingin berpartisipasi dalam bidang politik khususnya dalam hal pengambilan keputusan-keputusan mengenai kebijakan umum. Secara umum dapat dikatakan bahwa partisipasi politik adalah kegiatan seseorang atau kelompok orang untuk ikut secara aktif dalam kehidupan politik. McClosky (1972) berpendapat bahwa partisipasi politik adalah kegiatan- kegiatan sukarela dari warga masyarakat melalui mana mereka mengambil bagian dalam proses pemilihan penguasa, dan secara langsung atau tidak langsung, dalam proses pembentukan kebijakan umum.

Di Negara-negara demokrasi umumnya dianggap bahwa lebih banyak partisipasi masyarakat, lebih baik. Dalam alam pikiran ini, tingginya tingkat partisipasi menunjukkan bahwa warga mengikuti dan memahami masalah politik dan ingin melibatkan diri dalam kegiatan-kegiatan itu, tingginya tingkat partisipasi juga menunjukkan bahwa rezim yang sedang berkuasa memiliki keabsahan yang tinggi. Dan sebaliknya, rendahnya partisipasi politik di suatu Negara dianggap kurang baik karena menunjukkan rendahnya perhatian warga terhadap masalah politik, selain itu rendahnya partisipasi politik juga menunjukkan lemahnya legitimasi dari rezim yang sedang berkuasa.

\section{Pilkada Demokratis}

Pilkada merupakan salah satu kegiatan politik yang merupakan implementasi hak kedaulatan rakyat dalam memilih pemimpin untuk masa 5 tahun mendatang.Melalui Pilkada terjadi pergantian pemegang kekuasaan secara teratur, damai dan berkualitas. Menurut Peraturan Pemerintah No. 6 Tahun 2005 Tentang Pemilihan, Pengesahan, Pengangkatan dan Pemberhentian Kepala Daerah dan Wakil Kepala Daerah, Pemilihan kepala daerah adalah sarana pelaksana kedaulatan rakyat di wilayah propinsi dan/atau Kabupaten/Kota berdasarkan Pancasila dan UUD 1945 untuk memilih kepala 
daerah dan wakil kepala daerah. Pilkada juga merupakan terobosan baru dalam sistem politik Indonesia, khususnya untuk level pemerintahan lokal. Sebelum Pilkada, kepala daerah dipilih melaui sebuah proses politik yang tidak dapat disebut Pemilu, karena tidak melibatkan rakyat pemilih. Menurut Zuhro, dkk (2009:48) mengatakan bahwa Pilkada merupakan momentum untuk melakukan suksesi kepemimpinan lokal sebagai wujud implementasi demokrasi yang partisipatif. Pilkada merupakan pemilihan yang diselenggarakan di daerah otonom yang merupakan perintah dari perubahan UU No. 32 Tahun 2004 Tentang Pemerintahan Daerah.

Menururt Irtanto (2008:159) yang dimaksud Pilkada adalah suatu proses politik untuk memilih kepala daerah secara langsung. Terselenggaranya Pilkada merupakan amanat pasal 56 ayat (1) UU No. 32 Tahun 2004 yang menyatakan bahwa: Kepala Daerah dan Wakil Kepala Daerah dipilih dalam satu pasangan calon yang dilaksanakan secara demokratis berdasarkan asas langsung, umum, bebas, rahasia, jujur dan adil. Berdasarkan landasan hukum di atas, Pilkada merupakan kegiatan pemilihan umum yang bertujuan memilih kepala daerah dan wakil kepala daerah untuk daerah otonom tertentu, yang diharapkan mampu mewujudkan sistem politik yang lebih stabil dan berkualitas, karena terjadi proses pendewasaan pemilih, partai politik, penyelenggara dan media massa.

Lebih lanjut Sanit (1985: 157) mengatakan proses pelaksanaan Pemilu berpengaruh langsung kepada pembentukan budaya politik, sebab tingkah laku para kontestan dan penyelenggara Pemilu langsung dihayati oleh anggota masyarakat yang mengetahuinya, baik pengetahuan yang diperoleh melalui pengamatan, maupun melalui informasi. Selanjutnya sistem ini mengatur beberapa hal berikut ini yaitu jurus pencalonan kandidat, jurus pencoblosan suara, besar/bobot daerah pemilihan, lingkup daerah pemilihan dan jurus pengambilan keputusan

\section{Pilkada Sebagai Resolusi Konflik}

Resolusi konflik menurut Harjana terdiri dari 5 (lima) bentuk. Pertama, bersaing dan bertanding, menguasai, dan memaksa. Cara ini merupakan pendekatan terhadap konflik yang berciri menang-kalah. Kedua, kerjasama dan menghadapi. Dalam hal ini, pihak yang terlibat konflik bekerja sama dan mencari pemecahan konflik yang memuaskan kepentingan kedua belah pihak. Cara ini merupakan pendekatan menang-menang. Ketiga, kompromi dan 
berunding. Cara ini merupakan pendekatan terhadap konflik di mana pihakpihak yang berkonflik tidak ada yang menang/kalah. Keempat, menghindari atau menarik. Dalam pendekatan kalah-kalah ini, kedua belah pihak tidak memperjuangkan kepentingan masing-masing bahkan mereka tidak menarik perhatian pada perkara yang dikonflikkan. Kelima, menyesuaikan, memperlunak, dan menurut. Bentuk pengelolaan konflik ini merupakan pendekatan kalah menang (Hardjono, 1994: 49).

Tingkat keberhasilan sebuah resolusi konflik dikaitkan dengan efektivitas resolusi konflik. Efektivitas resolusi konflik secara umum lebih dilihat dalam 3 (tiga) tingkatan. Pertama, efektivitas yang tinggi yaitu upaya resolusi berhasil mentransformasikan konflik politik menjadi konsensus (Fatah, 2002: 47). Kedua, efektivitas semu. Resolusi konflik hanya berhasil menekan bentuk konflik politik dari permukaan atas ke bawah permukaan. Ketiga, efektivitas yang rendah, yaitu resolusi konflik yang tidak berhasil meresolusikan konflik menjadi konsensus, baik secara substansial maupun semu. Bentuk dari konflik ini biasanya dimatikan secara koersif / represif (Fatah, 2002: 56-57)

\section{Netralitas}

Netralitas menurut Kamus Besar Bahasa Indonesia (KBBI) adalah keadaan dan sikap netral, dalam arti tidak memihak, atau bebas. Menurut Mokhsen, Dwiputrianti, \& Muhammad (2018) netralitas ASN mengandung makna impartiality yaitu bebas kepentingan, bebas intervensi, bebas pengaruh, adil, objektif, dan tidak memihak. Sementara itu Marbun dalam Sri Hartini (2009) menyampaikan bahwa netralitas adalah bebasnya Pegawai Negeri Sipil dari pengaruh kepentingan partai politik tertentu atau tidak memihak untuk kepentingan partai politik tertentu atau tidak berperan dalam proses politik.

Apabila dikaitkan dengan penyelenggaraan Pilkada, netralitas dapat didefenisikan sebagai perilaku tidak memihak, atau tidak terlibat yang ditunjukan birokrasi pemerintahan dalam masa kampanye kandidat kepala daerah di ajang pemilukada baik secara diam-diam maupun terang-terangan (La Ode, 2013). Menurut La Ode (2013), ada dua indikator utama dari netralitas politik, yaitu:

a. Tidak terlibat, dalam arti tidak menjadi tim sukses calon kandidat pada masa kampanye atau menjadi peserta kampanye baik dengan menggunakan atribut partai atau atribut PNS. 
b. Tidak memihak, dalam arti tidak membantu dalam membuat keputusan dan/atau tindakan yang menguntungkan salah satu pasangan calon, tidak mengadakan kegiatan yang mengarah kepada keberpihakan terhadap salah satu pasangan calon Kepala Daerah/Wakil Kepala Daerah pada masa kampanye meliputi pertemuan, ajakan, himbauan, seruan, atau pemberian barang kepada PNS dalam lingkup unit kerjanya, anggota keluarga, dan masyarakat, serta tidak membantu dalam menggunakan fasilitas negara yang terkait dengan jabatan dalam rangka pemenangan salah satu calon pasangan Kepala Daerah/Wakil Kepala Daerah pada masa kampanye.

\section{Metode Penelitian}

Jenis penelitian ini adalah penelitian yang memperoleh data dari sumber data primer. Penulis memilih lokasi penelitian di yaitu Instansi ASN Provinsi Lampung. Sifat penelitian dalam ini deskriptif analisis bertujuan untuk mendeskripsikan secara sistematis, faktual dan akurat terhadap suatu populasi atau daerah tertentu, mengenai sifat-sifat; karakteristik-karakteristik atau faktor-faktor tertentu. Penelitian kualitatif yang menghasilkan data deskriptif berupa kata-kata tertulis atau lisan dari orang-orang dan perilaku yaang dapat diamati untuk diarahkan pada latar dan individu secara holistik/utuh. Penelitian ini menggunakan perpaduan pendekatan perundang-undangan (statute approach), dan pendekatan kasus (case approach).

Kegiatan pengumpulan data lapangan dimaksudkan untuk mendapatkan masukan bagi perbaikan sistem pengawasan netralitas ASN. Pengumpulan data melalui website pada Komisi Aparatur Sipil Negara Tahun 2019-2020.

\section{Pembahasan}

\section{Regulasi Netralitas ASN Pilkada 2020}

a. Undang Undang Nomor 5 Tahun 2014 Tentang Aparatur Sipil Negara (ASN)

Pasal 2 huruf $f$, menyatakan bahwa salah satu asas penyelenggaraan kebijakan dan manajemen ASN adalah "Netralitas". Asas Netralitas ini berarti bahwa setiap pegawai ASN tidak berpihak dari segala bentuk pengaruh manapun dan tidak memihak kepada kepentingan siapapun. Selanjutnya, Pasal 
87 ayat 4 huruf c, menyatakan bahwa PNS diberhentikan dengan tidak hormat karena menjadi anggota dan/atau pengurus partai politik.

Selain itu Aparatur Sipil Negara yang akan mencalonkan diri menjadi kepala daerah harus melakukan pengunduran diri secara tertulis sebagaimana diatur dalam Pasal 119 dan Pasal 123 ayat 3, berdasarkan putusan Mahkamah Konstitusi Nomor 41/PUU-XIII/2014 Tanggal 6 Juli 2015, "PNS yang mencalonkan diri atau dicalonkan menjadi Gubernur/Wakil Gubernur, Bupati/Wakil Bupati, Walikota/Wakil Walikota wajib menyatakan pengunduran diri secara tertulis sebagai PNS sejak ditetapkan sebagai calon peserta pemilihan Gubernur/Wakil Gubernur, Bupati/Wakil Bupati, Walikota/Wakil Walikota" PNS yang tidak melaksanakan ketentuan tersebut dijatuhi sanksi hukuman disiplin.

\section{b. Undang-Undang Nomor 10 Tahun 2016 tentang Perubahan Kedua Atas Undang-Undang Nomor 1 Tahun 2015 Tentang Penetapan Peraturan Pemerintah Nomor 1 Tahun 2014 Tentang Pemilihan Gubernur, Bupati dan Walikota Menjadi Undang- Undang.}

Hibauan netralitas tidak hanya ditujukan pada ASN, hal ini juga dihimbau pada pasangan calon untuk tidak melibatkan ASN dalam kampanye, sebagai mana diatur dalam Pasal 70 ayat 1 huruf b; Pasangan calon dilarang melibatkan Aparatur Sipil Negara, Anggota Kepolisian Negara Republik Indonesia dan Anggota Tentara Nasional Indonesia. Selanjutnya, Pasal 71 ayat 1; Pejabat negara, pejabat daerah, pejabat aparatur sipil negara, anggota TNI/POLRI, dan Kepala Desa atau sebutan lain/Lurah dilarang membuat keputusan dan/atau tindakan yang menguntungkan atau merugikan salah satu pasangan calon. Berdasarkan undang-undang tersebut, dapat disimpulkan bahwa baik pihak ASN maupun pasangan calon kepala daerah dihimbau untuk tetep menjaga netralitas.

\section{c. PP Nomor 42 Tahun 2004 Tentang Pembinaan Jiwa Korps dan Kode Etik Pegawai Negeri Sipil}

Pasal 11 huruf c menyatakan bahwa dalam hal etika terhadap diri sendiri PNS wajib menghindari konflik kepentingan pribadi, kelompok ataupun golongan. Maka PNS dilarang melakukan perbuatan yang mengarah pada keberpihakan salah satu calon atau perbuatan yang mengindikasikan terlibat dalam politik praktis/berafiliasi dengan partai politik, semisal: PNS dilarang 
melakukan pendekatan terhadap partai politik terkait rencana pengusulan dirinya ataupun orang lain sebagai bakal calon Kepala Daerah/Wakil Kepala Daerah.

d. Peraturan Pemerintah Republik Indonesia Nomor 53 Tahun 2010 Tentang Disiplin Pegawai Negeri Sipil

Pasal 4; angka 12, memberikan dukungan kepada calon Presiden/Wakil Presiden, Dewan Perwakilan Rakyat, Dewan Perwakilan Daerah, atau Dewan Perwakilan Rakyat Daerah dengan cara: a. ikut serta sebagai pelaksana kampanye; b. menjadi peserta kampanye dengan menggunakan atribut partai atau atribut PNS; c. sebagai peserta kampanye dengan mengerahkan PNS lain dan atau; d. sebagai peserta kampanye dengan menggunakan fasilitas Negara

\section{Pelanggaran Regulasi Netralitas Pilkada 2020}

Kementerian Dalam Negeri (Kemendagri) menegur 67 kepala daerah dan memberi waktu tiga hari untuk menindaklanjuti rekomendasi Komisi Aparatur Sipil Negara (KASN) terkait pelanggaran netralitas ASN dalam Pilkada 2020. Kepala Daerah yang tidak menindaklanjuti rekomendasi tersebut, akan dikenai sanksi, mulai dari sanksi moral hingga hukuman disiplin.

Ada pun kepala pemerintahan provinsi, kabupaten dan kota yang mendapat teguran soal netralitas $\underline{A S N}$ adalah Gubernur Jambi, Gubernur Jawa Timur, Gubernur Kepulauan Riau, Gubernur Lampung, Gubernur Nusa Tenggara Barat, Gubernur Sulawesi Barat, Guberur Sulawesi Selatan, Gubernur Sulawesi Tengah, Gubernur Sulawesi Tenggara, Gubernur Sulawesi Utara, Bupati Asahan, Bupati Asmat, Wlikota Bandung, Bupati Banggai, Bupati Banjar, Bupati Boven Digul, Bupati Bulukumba, Bupati Buton Utara, Bupati Cianjur, Bupati Dompu, Bupati Gowa, Bupati Halmahera Timur, Bupati Indragiri Hulu, Bupati Jember, Bupati Kepulauan Meranti', Bupati Kepulauan Selayar, Bupati Konawe, Bupati Konawe Utara, Bupati Kuantan Singingi, Bupati Limapuluh, Bupati Lingga, Bupati Lombok Utara, Bupati Majene, Bupati Mamberamo Raya, Bupati Maros, Bupati Merauke, Bupati Mojokerto, Bupati Muaro Jambi, Bupati Muna, Bupati Muna Barat, Bupati Nias Selatan, Bupati Pandeglang, Bupati Pangkajene dan Kepulauan, Bupati Pasangkayu, Bupati Pelalawan, Bupati Pesisir Barat, Bupati Sidoarjo, Bupati Sijunjung, Bupati Simalungun, Bupati Solok, Bupati Sukabumi, Bupati Sumba Timur, 
Bupati Supiori, Bupati Tana Toraja, Bupati Tasikmalaya, Bupati Tojo Unauna, Bupati Toli-toli, Bupati Wakatobi, Walikota Batam, Walikota Binjai, Walikota Bontang, Walikota Makassar, Walikota Mataram', Walikota Pariaman, Walikota Samarinda, Walikota Solok, dan Walikota Surabaya.

Pemungutan suara Pilkada 2020 akan diselenggarakan satu minggu lagi, sayangnya pelanggaran netralitas Aparatur Sipil Negara (ASN) masih menjadi momok dalam pelanggaran pemilihan. Berdasarkan data yang dihimpun Bawaslu hingga 16 November 2020 terdapat 1.038 pelanggaran netralitas ASN yang terdiri dari 934 merupakan temuan Bawaslu sedangkan 104 laporan masyarakat. Dari data tersebut KASN telah mengeluarkan rekomendasi 938 kasus, 5 kasus telah diproses, dan 95 kasus dinyatakan bukan pelanggaran.

Adapun bentuk-bentuk pelanggaran netralitas ASN, diantaranya memengaruhi warga dengan politik uang untuk memilih paslon tertentu, melarang/menghalangi pemasangan alat peraga kampanye paslon tertentu. Lalu ada pula penggunaan fasilitas dan anggaran negara, memengaruhi perangkat desa untuk berpihak kepada paslon tertentu, menyalahgunakan kewenangan dalam merencanakan program dan distribusi bantuan sosial. Selain itu ada pelanggaran dengan cara terlibat dalam kampanye, terlibat sebagai tim kampanye atau tim sukses paslon, membuat kebijakan dalam bentuk Surat Keputusan, dan menggerakkan struktur birokrasi/memengaruhi/ mengintimidasi para pegawai bawahan di jajaran.

Pelanggaran netralitas juga pernah terjadi di beberapa provinsi pada Pilkada 2018, salah satunya dilaksanakan di Provinsi Jawa Barat dengan pelanggaran netralitas yang terjadi tertinggi ke-empat di Indonesia. Menurut data dari KASN per Juni 2018 terdapat 51 ASN yang terlibat. Sebaran wilayah pelanggaran Netralitas ASN di Jawa Barat dalam rentang waktu Januari - Juni 2018 sebagai berikut: Kota Bandung 34.1\%, Kab. Majalengka 20.5\%, Kab. Bandung Barat $13.6 \%$, dan Kota Cirebon $6.8 \%$, sebanyak $25 \%$ pelanggaran netralitas lainnya tersebar di wilayah lain. Jika dikelompokan berdasarkan jenis pelanggaran dalam kasus di Jawa Barat sebagai berikut: foto bersama paslon $47.7 \%$, menghadiri deklarasi calon $27.3 \%$ dan kampanye/sosialisasi melalui media sosial $9.1 \%$ ASN. Sisanya sebesar $15.9 \%$ adalah jenis pelanggaran lainnya (Mokhsen, Dwiputrianti, \& Muhammad, 2018). 


\section{Kelemahan Regulasi Netralitas Pilkada 2020}

Patronasi politik menghambat penerapan asas netralitas ASN. Sistem politik yang berlaku menelan biaya yang sangat tinggi. Hal ini mengakibatkan para calon kepala daerah/pejabat politik harus memiliki modal yang cukup banyak untuk dapat memenangkan pemilu. Pejabat politik khususnya kepala daerah yang terpilih memiliki kewenangan dan kekuasaan dalam mengelola sumberdaya ASN. Hal ini sangat memungkinkan bagi mereka menggunakan kekuasaan tersebut dengan memobilisasi dukungan pegawai ASN yang mempunyai kewenangan atas anggaran dan asset negara/daerah. Hal ini menyulitkan pegawai ASN untuk bersikap netral.

Kendala di tingkat mikro dalam menegakkan asas netralitas antara lain adalah sebagai berikut:

a. Mindset pegawai ASN yang cenderung berpihak pada atasan yang diwariskan oleh birokrasi politik pada era pemerintahan orde baru. Banyak ASN tidak memahami prinsip-prinsip netralitas dan tidak menyadari bahwa apa yang mereka lakukan melanggar ketentuan yang berlaku.

b. Kesadaran pegawai ASN yang masih rendah akan pentingnya bersikap netral dalam menyelenggarakan pemerintahanan, pembangunan, dan pelayanan publik serta menganggap keberpihakan merupakan sesuatu yang lumrah.

c. Sikap sebagian pegawai ASN yang lebih mengutamakan cara mudah dalam mencapai karier yang lebih tinggi dengan menunjukkan loyalitas kepada atasan dari pada menunjukkan profesionalitas dan kinerja.

d. Keengganan masyarakat dalam melaporkan pelanggaran netralitas ASN karena ketidaktahuan ataupun factor budaya yang membuat pengawasan masyarakat tidak berfungsi secara efektif. masyarakat Indonesia yang enggan untuk melaporkan kasus pelanggaran netralitas yang ada di lingkungan terdekatnya bisa dikatakan juga sebagai permasalahan tersendiri dalam sistem pengawasan netralitas ASN. Temuan berupa keengganan masyarakat dalam melaporkan kasus pelanggaran yang ada ini disebebkan oleh beberapa faktor, yaitu:

1) Kultur masyarakat Indonesia yang "merasa tidak enak" kepada sesama rekan kerja/tetangga/kerabat, dianggapnya jika 
melaporkan pelanggaran netralitas yang terjadi di lingkungan terdekatnya akan merusak hubungan yang selama ini terjalin, ataupun alasan emosional lainnya. Banyak kasus pelanggaran netralitas ASN tidak terungkap karena kultur ini.

2) Pelanggaran netralitas ASN dianggap sebagai hal lumrah. Masih banyak masyarakat Indonesia yang menganggap kasus pelanggaran netralitas yang terjadi di lingkungan sekitarnya sebagai hal biasa dan tidak perlu dibesar besarkan termasuk tidak perlu dilaporkan kepada lembaga terkait.

3) Sistem pengawasan terhadap pelanggaran netralitas ASN yang belum optimal yang disebabkan terbatasnya kemampuan KASN yang tidak mempunyai perwakilan di daerah dan hanya didukung oleh pegawai dan anggaran dalam jumlah yang terbatas.

4) Rekomendasi KASN diabaikan oleh Pejabat Pembina Kepegawaian (PPK). Akibatnya pemberian sanksi kepada ASN yang melakukan pelanggaran menjadi tidak efektif dan tidak menimbulkan efek jera.

\section{Kesimpulan}

Pemungutan suara Pilkada 2020 akan diselenggarakan satu minggu lagi, sayangnya pelanggaran netralitas Aparatur Sipil Negara (ASN) masih menjadi momok dalam pelanggaran pemilihan. Berdasarkan data yang dihimpun Bawaslu hingga 16 November 2020 terdapat 1.038 pelanggaran netralitas ASN yang terdiri dari 934 merupakan temuan Bawaslu sedangkan 104 laporan masyarakat. Dari data tersebut KASN telah mengeluarkan rekomendasi 938 kasus, 5 kasus telah diproses, dan 95 kasus dinyatakan bukan pelanggaran.

Adapun bentuk-bentuk pelanggaran netralitas ASN, diantaranya memengaruhi warga dengan politik uang untuk memilih paslon tertentu, melarang/menghalangi pemasangan alat peraga kampanye paslon tertentu. Lalu ada pula penggunaan fasilitas dan anggaran negara, memengaruhi perangkat desa untuk berpihak kepada paslon tertentu, menyalahgunakan kewenangan dalam merencanakan program dan distribusi bantuan sosial. Selain itu ada pelanggaran dengan cara terlibat dalam kampanye, terlibat sebagai tim kampanye atau tim sukses paslon, membuat kebijakan dalam bentuk Surat Keputusan, dan menggerakkan struktur birokrasi/memengaruhi/ mengintimidasi para pegawai bawahan di jajaran. 
Pengawasan Netralitas pegawai ASN menjadi salah satu hal yang harus dikuatkan dalam mengatasi permasalahan netralitas ASN agar reformasi birokrasi di pemerintahan berjalan dengan cepat. Banyaknya pelanggaran yang terjadi 3 tahun terakhir ini menjadi evidence bahwa perlunya pengawasan Netralitas ASN yang efektif, kolaboratif, dan komprehensif. Berdasarkan hasil kajian yang telah dilaksanakan, rekomendasi yang bisa diberikan adalah meningkatkan pemahaman pegawai terhadap asas netralitas ASN, membangun kolaborasi yang efektif dengan instansi lain yang terkait, Kementerian PANRB, Kementerian Dalam Negeri, BKN, dan Bawaslu, dan pemberian sanksi yang lebih berat kepada pegawai yang melanggar.

\section{DAFTAR PUSTAKA}

Hardjono, A. M. (1994). Konflik di Tempat Kerja. Kanisius: Yogyakarta

Irtanto. (2008). Dinamika Politik Lokal Era Otonomi Daerah. Yogyakarta: Pustaka Pelajar

La Ode, A., (2015). Development Of Learning Devices Of Cybernetic Cooperative In Discussing The Simplex Method In Mathematics Education Students Of FKIP UHO. International Journal of Education and Research,3(2): 189-198

McClosky, Herbert. (1972). Political Participation. International Encyclopedia of the Social Science. New York : The Macmillan Company

Mokhsen, N., Dwiputrianti, S., \& Muhammad, S. (2018). Pengawasan Netralitas Aparatur Sipil Negara Edisi Pertama. Jakarta: Komisi Aparatur Sipil Negara

Peraturan Pemerintah Republik Indonesia Nomor 53 Tahun 2010 Tentang Disiplin Pegawai Negeri Sipil

Peraturan Pemerintah Nomor 6 Tahun 2005 tentang Pemilihan, Pengesahan, Pengangkatan dan Pemberhentian Kepala Daerah dan Wakil Kepala Daerah.

Peraturan Pemerintah Nomor 42 Tahun 2004 Tentang Pembinaan Jiwa Korps dan Kode Etik Pegawai Negeri Sipil

Sanit, A. (1985). Perwakilan Politik Indonesia, Yogyakarta: CV. Rajawali. 
272 | Dewi Mustika Sari Regulasi Netralitas Aparatur...

Saputra, A. D. (2020). Pencegahan dan Penindakan Pelanggaran Netralitas Aparatur Sipil Negara (ASN) oleh Bawaslu Kota Palopo Pada Pemilu 2019. Public Administration Journal

Sri Hartini. 2009. Penegakan Hukum Netralitas Pegawai Negeri Sipil (PNS). Jurnal Dinamika Hukum Vol. 9, No. 3

Undang-Undang Nomor 10 Tahun 2016 tentang Perubahan Kedua Atas UndangUndang Nomor 1 Tahun 2015 Tentang Penetapan Peraturan Pemerintah Nomor 1 Tahun 2014 Tentang Pemilihan Gubernur, Bupati dan Walikota Menjadi Undang-Undang.

Zuhro, Siti R, dkk.2009.Demokrasi Lokal perubahaan dan kesinambungan Nilainilai BudayaPolitik Lokal Di Jawa Timur, Sumbar,S ulssel dan Bali. 